CZASOPISMO INŻYNIERII LĄDOWEJ, ŚRODOWISKA I ARCHITEKTURY JOURNAL OF CIVIL ENGINEERING, ENVIRONMENT AND ARCHITECTURE

JCEEA, t. XXXIII, z. 63 (2/II/16), kwiecień-czerwiec 2016, s. 209-224

\author{
Sabina KORDANA ${ }^{1}$
}

Daniel SŁYŚ

\title{
ANALIZA SWOT ZASTOSOWANIA SYSTEMÓW INFILTRACJI WÓD OPADOWYCH NA TERENIE OSIEDLI MIESZKANIOWYCH
}

\begin{abstract}
Obserwowany współcześnie dynamiczny rozwój sektorów budownictwa i transportu powoduje sukcesywne zwiększanie się udziału powierzchni utwardzonych w całkowitej powierzchni zlewni. Następstwem tego procesu jest wzrost ilości wód deszczowych ujmowanych w systemy kanalizacji krytej i odprowadzanych do odbiornika, co skutkuje częstym przeciążaniem istniejących kolektorów kanalizacyjnych oraz pogorszeniem stanu rzek. Zapobieganie tym zjawiskom jest możliwe tylko w przypadku stosowania zrównoważonych systemów zagospodarowania wód opadowych, do których zaliczane są między innymi systemy infiltracyjne. Możliwości aplikacji urządzeń rozsączających wody deszczowe są jednak uzależnione od szeregu czynników, takich jak warunki gruntowo-wodne czy charakterystyka ilościowa i jakościowa odprowadzanego do gruntu medium. W celu określenia strategii rozwoju systemów przeznaczonych do infiltracji wód opadowych przeprowadzono analizę mocnych i słabych stron tych systemów, jak również potencjalnych szans i zagrożeń wynikających z ich implementacji na terenie osiedli mieszkaniowych. Jako narzędzie wykorzystano analizę SWOT/TOWS, będącą jedną z metod planowania strategicznego. Przeprowadzone badania wskazują na duży potencjał rozpatrywanych systemów, który wynika ze sprzyjających ich rozwojowi szans, co powoduje potrzebę możliwie największego wykorzystania tych szans przy pomocy mocnych stron systemów infiltracyjnych. Aby było to możliwe, konieczne jest jednak podjęcie działań ukierunkowanych na osłabienie wad systemów infiltracyjnych oraz rozwój świadomości ekologicznej mieszkańców, gdyż tylko kompleksowe podejście do kwestii rozsączania wód deszczowych pozwoli w pełni wykorzystać atuty urządzeń infiltracyjnych.
\end{abstract}

Słowa kluczowe: analiza SWOT/TOWS, gospodarka wodami opadowymi, systemy rozsączające wody deszczowe, zrównoważony rozwój

\footnotetext{
${ }^{1}$ Autor do korespondencji / corresponding author: Sabina Kordana, Politechnika Rzeszowska, Wydział Budownictwa, Inżynierii Środowiska i Architektury, Zakład Infrastruktury i Ekorozwoju, al. Powstańców Warszawy 6, 35-959 Rzeszów, tel. +48 17 8651071, e-mail: sk@ prz.edu.pl

2 Daniel Słyś, Politechnika Rzeszowska, Wydział Budownictwa, Inżynierii Środowiska i Architektury, Zakład Infrastruktury i Ekorozwoju, al. Powstańców Warszawy 6, 35-959 Rzeszów, tel. +48 17 8651784, e-mail: daniels@ @rz.edu.pl
} 


\section{Wprowadzenie}

Jednym z głównych następstw obserwowanych w ostatnich latach zmian klimatu jest wzrost intensywności opadów ekstremalnych [14, 30]. Konsekwencją tego zjawiska jest regularne zwiększanie się szczytowych przepływów ścieków deszczowych w kolektorach kanalizacyjnych, które już teraz są przeciążone na skutek dynamicznego rozwoju sektorów budownictwa i transportu. Kontynuowanie w takich warunkach polityki ,końca rury”, która w Polsce wciąż jest powszechna, może skutkować nieodwracalnymi zmianami w otaczającym nas środowisku, a w rezultacie także pogorszeniem komfortu życia obecnego i przyszłych pokoleń.

Wobec powyższych faktów istotne jest rozwijanie oraz wdrażanie zrównoważonych rozwiązań systemów zarządzania wodami deszczowymi, których implementacja $w$ danych warunkach będzie uzasadniona pod względem technicznym i ekonomicznym. Rozwiązania te opierają się na idei zagospodarowania wód opadowych w obrębie zlewni, w której powstają, bądź spłaszczenia hydrogramu odpływu tych wód ze zlewni do odbiornika. W pierwszym przypadku zastosowanie mogą znaleźć systemy zakładające infiltrację spływających z odwadnianej powierzchni wód opadowych do gruntu [1,29] oraz instalacje gospodarczego wykorzystania wód deszczowych $[8,13]$. Z kolei w sytuacji, gdy konieczne jest odprowadzenie ścieków opadowych do odbiornika, wykonane mogą zostać systemy przeznaczone do ich okresowej retencji $[7,21]$.

Przedmiotem badań, których wyniki opisano w niniejszym artykule, jest pierwszy z przytoczonych sposobów zagospodarowania wód deszczowych, to jest ich infiltracja do gruntu. Proces przesączania wody opadowej przez przestrzenie między ziarnami gruntu jest wynikiem działania siły ciężkości, a jego intensywność jest uzależniona od szeregu czynników, takich jak [4, 26]: wilgotność gleby, przepuszczalność gruntu i ukształtowanie terenu, intensywność i charakterystyka opadów, temperatura i wilgotność powietrza, wiatr, szata roślinna czy sposób zagospodarowania zlewni. Szczególnie ostatnia z wymienionych determinant efektywności procesu infiltracji wód deszczowych jest ściśle związana z działalnością człowieka. Postępująca urbanizacja powoduje bowiem wzrost udziału powierzchni utwardzonych w całkowitej powierzchni zlewni, co znacznie ogranicza możliwość naturalnej infiltracji wód opadowych w głąb gruntu, i wymusza prowadzenie tego procesu w specjalnie do tego przeznaczonych urządzeniach.

Proces infiltracji wód opadowych może być realizowany zarówno w urządzeniach podziemnych, jak i powierzchniowych, co przedstawiono na rysunku 1. Wykorzystanie tych urządzeń jest procesem proekologicznym, przynoszącym wiele korzyści nie tylko dla środowiska, ale także dla eksploatatorów systemów odwodnieniowych oraz osób zamieszkujących odwadniane tereny. Warto podkreślić, że obiekty przeznaczone do infiltracji wód deszczowych, oprócz ich pierwotnego przeznaczenia, mogą pełnić także szereg dodatkowych funkcji 
w zlewniach miejskich. Przykładowo w pracy [6] opisano warianty współpracy pompy ciepła z systemami rozsączania wód opadowych w produkcji roślinnej. Z kolei Sleegers i Brabec [25] wskazują na znaczny potencjał estetyczny urządzeń infiltracyjnych, który często pozostaje niewykorzystany. Problemem pozostaje jednak ograniczenie możliwości zastosowania poszczególnych rozwiązań systemów infiltracyjnych, które związane jest głównie z jakością odprowadzanych wód deszczowych oraz charakterystyką gruntowo-wodną zlewni [18].

\section{INFILTRACJA WÓD OPADOWYCH DO GRUNTU}

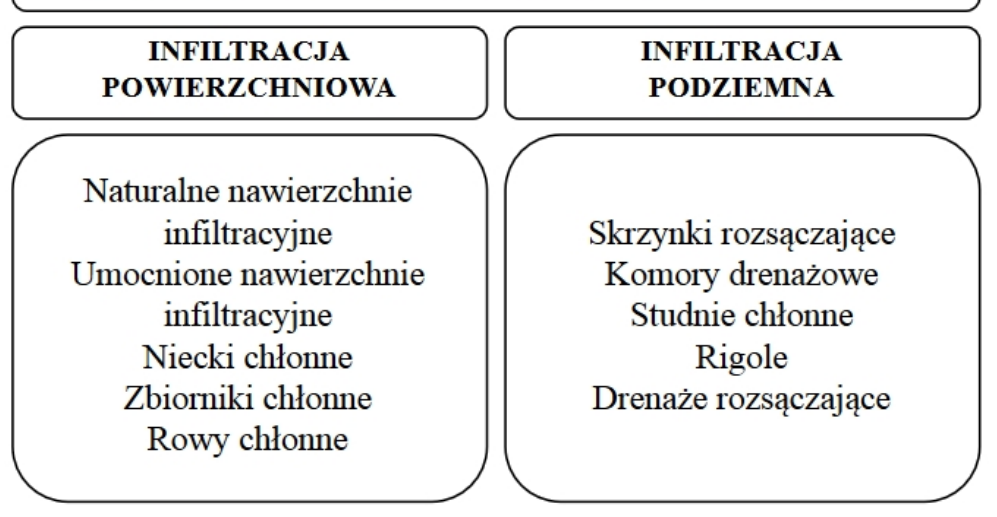

Rys. 1. Urządzenia przeznaczone do infiltracji wód opadowych do gruntu (na podstawie: [26])

Fig. 1. Devices for stormwater infiltration into the ground (based on: [26])

W celu oceny racjonalności zastosowania systemów infiltracyjnych przeznaczonych do zagospodarowania wód opadowych pochodzących z terenu osiedli mieszkaniowych zbadano mocne i słabe strony takiego rozwiązania, jak również potencjalne korzyści i zagrożenia z niego wynikające. Jako narzędzie wykorzystano analizę SWOT, której założenia opisano w kolejnym punkcie artykułu.

\section{Metodyka badań}

Analiza SWOT (Strengths - Weaknesses - Opportunities - Threats) jest jedną z najbardziej uniwersalnych i przejrzystych metod planowania strategicznego, dzięki czemu może zostać wykorzystana w przypadku konieczności oceny przedsiębiorstw, organizacji, krajów, projektów biznesowych, a nawet ludzi $[2,22]$. Znajduje zastosowanie także $\mathrm{w}$ obszarach związanych $\mathrm{z}$ inżynierią środowiska, przykładowo w celu diagnostyki stanu sektora odnawialnych źródeł energii $[10,11]$, oceny metod zapobiegania zanieczyszczeniom środowiska $[28,31]$ czy efektywnego zarządzania zasobami wodnymi $[3,12]$. W przypadku 
gospodarki wodami opadowymi wykorzystanie analizy SWOT wciąż należy jednak do rzadkości i ogranicza się głównie do systemów gospodarczego wykorzystania wód deszczowych [15].

Metoda ta obejmuje analizę czynników pozytywnych i negatywnych, co przedstawiono na rysunku 2 . Do pierwszej grupy zaliczane są mocne strony ocenianego projektu oraz potencjalne szanse związane $\mathrm{z}$ jego realizacją, natomiast czynniki negatywne to jego słabe strony oraz przewidywane zagrożenia. Mocne i słabe strony projektu, nazywane często zaletami i wadami, należą do czynników wewnętrznych. Mocne strony pozwalają wykorzystać nadarzające się szanse oraz ułatwiają przezwyciężanie ewentualnych zagrożeń. Słabe strony są natomiast powodem niewykorzystania pojawiających się szans oraz wzrostu podatności na zagrożenia [22]. Potencjalne szanse i zagrożenia są z kolei czynnikami zewnętrznymi, na które nie ma się wpływu. Mogą to być zarówno czynniki wymierne, jak i niewymierne, a ich przydzielenie do danej grupy jest każdorazowo uzależnione od kontekstu przeprowadzanych badań [2].

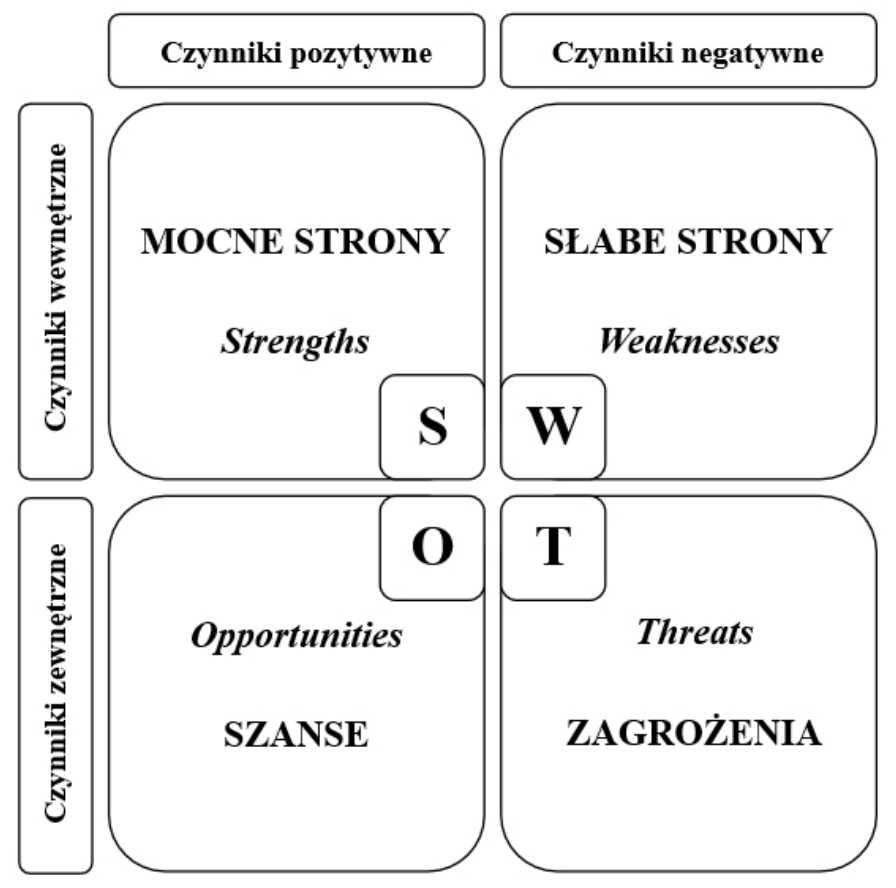

Rys. 2. Schemat analizy SWOT

Fig. 2. SWOT analysis diagram

Do istotnych etapów analizy SWOT zaliczyć należy także określenie ważności czynników przyporządkowanych do poszczególnych grup oraz zbadanie 
powiązań między nimi. Powiązania te można określić odpowiadając na następujące pytania [2]:

- Czy zidentyfikowana mocna strona ocenianego podmiotu/przedsięwzięcia umożliwia wykorzystanie nadarzającej się szansy?

- Czy zidentyfikowana mocna strona ocenianego podmiotu/przedsięwzięcia umożliwia przezwyciężenie pojawiającego się zagrożenia?

- Czy zidentyfikowana słaba strona ocenianego podmiotu/przedsięwzięcia uniemożliwia wykorzystanie nadarzającej się szansy?

- Czy zidentyfikowana słaba strona ocenianego podmiotu/przedsięwzięcia intensyfikuje pojawiające się zagrożenie?

Niekiedy wykorzystywana jest również analiza powiązań TOWS, która jest odwrotnością analizy SWOT i stanowi jej uzupełnienie. Istotą analizy TOWS jest określenie, czy poszczególne szanse są w stanie spotęgować silne oraz osłabić słabe strony oraz czy przewidywane zagrożenia będą ograniczać silne i wzmacniać słabe strony [20].

$\mathrm{Na}$ podstawie przypisanych kolejnym elementom wag, których suma dla danej grupy powinna wynosić 1,0 , oraz wyników analizy powiązań pomiędzy zdefiniowanymi czynnikami określa się następnie strategię rozwoju badanego podmiotu bądź przedsięwzięcia [20].

\section{Analiza SWOT jako narzędzie oceny systemów infiltracji wód opadowych}

\subsection{Identyfikacja czynników opisujących proces rozsączania wód deszczowych}

W celu identyfikacji strategii rozwoju systemów przeznaczonych do infiltracji wód deszczowych odprowadzanych z terenu osiedli mieszkaniowych wyznaczono mocne i słabe strony tych elementów infrastruktury miejskiej, jak również potencjalne szanse i zagrożenia związane z ich implementacją. Na rysunku 3 przedstawiono po 5 najważniejszych czynników przyporządkowanych do poszczególnych grup. Czynniki te są rozłączne, dzięki czemu możliwe jest przeprowadzenie analizy powiązań między nimi oraz ocena rozpatrywanych systemów zagospodarowania wód deszczowych.

Do mocnych stron systemów przeznaczonych do infiltracji wód opadowych do gruntu zaliczyć należy zredukowanie ilości ścieków deszczowych odprowadzanych do odbiornika, któremu towarzyszy ograniczenie ładunku zanieczyszczeń wprowadzanego wraz z tymi ściekami do wód powierzchniowych. Zmniejszenie ilości wód deszczowych kierowanych do rzek pozwala także odciążyć istniejące kolektory kanalizacyjne oraz obiekty na nich zlokalizowane, dzięki czemu możliwe jest wygospodarowanie przepustowości dla nowych podłączeń. W przypadku występowania sprzyjających warunków istnieje również możli- 
wość całkowitego wyeliminowania tradycyjnej kanalizacji deszczowej czy ogólnospławnej na rzecz rozwiązań zrównoważonych, gdyż różnorodność konstrukcji stosowanych urządzeń pozwala na ich dopasowanie do praktycznie każdego sposobu zagospodarowania zlewni.

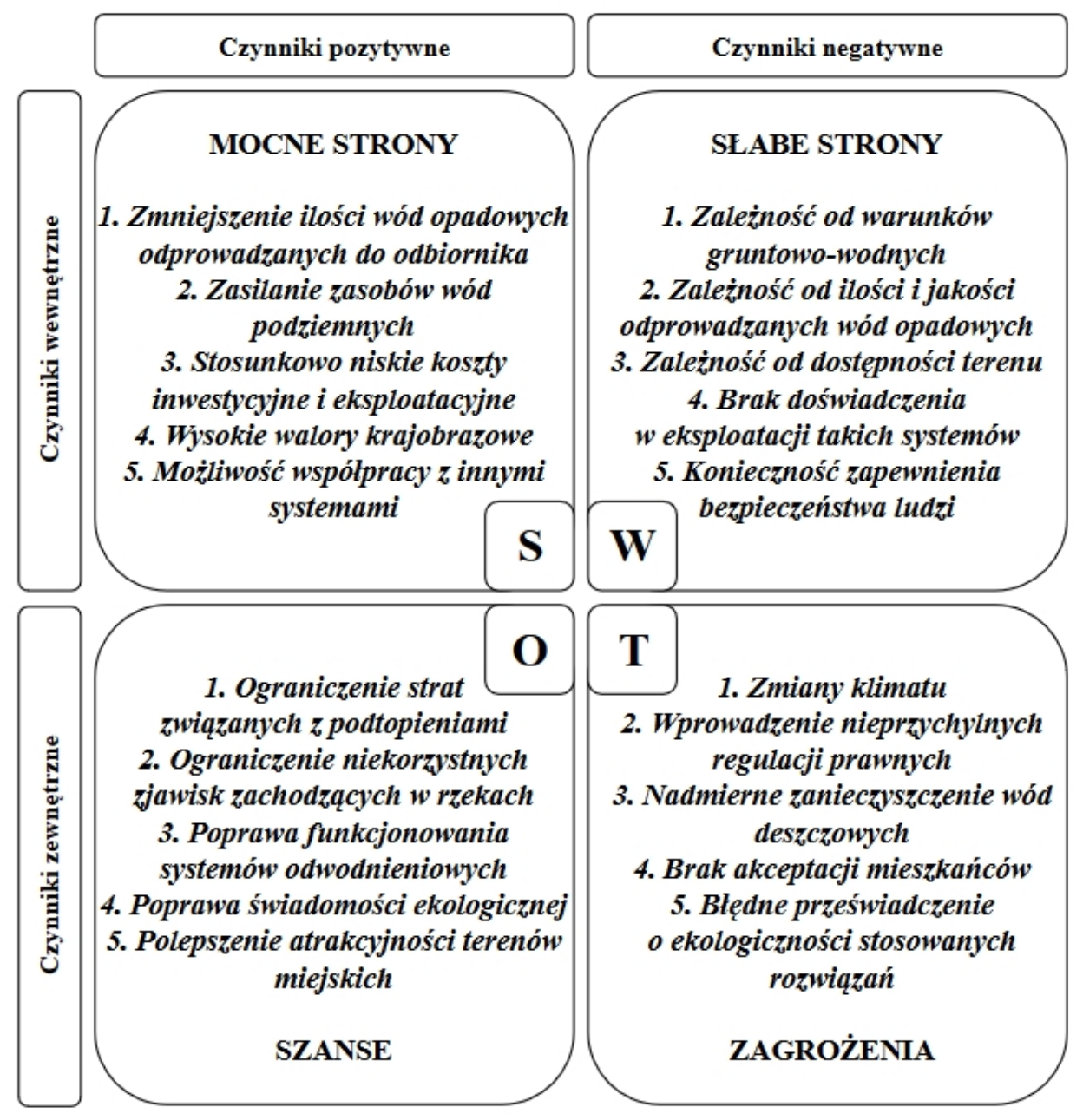

Rys. 3. Analiza SWOT systemów przeznaczonych do infiltracji wód opadowych

Fig. 3. SWOT analysis of stormwater infiltration devices

Zaletą zastosowania rozpatrywanych systemów jest też zasilanie zasobów wód podziemnych. Woda deszczowa, infiltrując między cząsteczkami gruntu, przedostaje się bowiem do strefy saturacji, co umożliwia odpływ wód gruntowych w kierunku cieku lub zbiornika wodnego, który jest z nimi powiązany hydraulicznie [4]. Regularne zasilanie zasobów wód podziemnych pozwala tak- 
że ograniczyć ryzyko potencjalnego niedoboru wody, a będący efektem rozsączania wody opadowej wzrost wilgotności gleby przyczynia się do poprawy stanu roślinności na odwadnianym terenie.

Pomimo niewątpliwych zalet związanych ze zredukowaniem ilości wód deszczowych odprowadzanych poza obręb zlewni, implementacja systemów infiltracyjnych wymaga poniesienia pewnych nakładów inwestycyjnych, których wysokość uzależniona jest głównie od sposobu realizacji tego procesu [16]. Doświadczenia pokazują jednak, że przeciętny koszt wykonania urządzeń przeznaczonych do infiltracji wód deszczowych, podobnie jak i ich eksploatacji, jest zdecydowanie niższy niż w przypadku tradycyjnej kanalizacji [23], co stanowi dodatkową mocną stronę analizowanych systemów.

Kolejnym atutem systemów infiltracyjnych są ich walory estetyczne. Dotyczy to przede wszystkim urządzeń przeznaczonych do powierzchniowej infiltracji wód opadowych, które w przypadku odpowiedniego zaprojektowania i wkomponowania w środowisko mogą tworzyć elementy małej architektury w zlewniach zurbanizowanych. Pozwala to podnosić walory krajobrazowe okolicy oraz wpływa pozytywnie na mikroklimat i samopoczucie mieszkańców.

Ostatnią mocną stroną urządzeń rozsączających wody opadowe, którą uwzględniono $\mathrm{w}$ analizie SWOT, jest możliwość ich współpracy z innymi systemami. Mogą to być zarówno odmienne rozwiązania systemów zagospodarowania wód deszczowych, obejmujące ich retencję i wykorzystanie gospodarcze, jak i instalacje przeznaczone do celów niezwiązanych z gospodarką wodami opadowymi. Dla przykładu, wsiąkająca w głąb gruntu woda opadowa może zostać wykorzystana do podniesienia wydajności gruntowego wymiennika ciepła $[6,19]$. Niektóre $\mathrm{z}$ analizowanych elementów infrastruktury miejskiej mogą także pełnić rolę parkingów [17], a odpowiednio zaprojektowane obiekty trawiaste - oczyszczalni spływów powierzchniowych [9].

Do słabych stron systemów przeznaczonych do infiltracji wód opadowych do gruntu zaliczyć należy natomiast uzależnienie racjonalności ich zastosowania od warunków gruntowo-wodnych, to jest przepuszczalności gruntu oraz położenia zwierciadła wód gruntowych. Optymalne warunki dla prowadzenia procesu infiltracji występują w gruntach charakteryzujących się wartością współczynnika filtracji rzędu $10^{-6}-10^{-3} \mathrm{~m} / \mathrm{s}$. Wykorzystanie urządzeń rozsączających wody opadowe w gruntach o większej przepuszczalności skutkuje koniecznością zastosowania dodatkowych urządzeń do oczyszczania wód deszczowych. Z kolei mniejsza przepuszczalność gruntu całkowicie wyklucza możliwość zastosowania rozpatrywanych systemów. Również płytko położony poziom wód gruntowych może stać się przyczyną niemożności zastosowania konkretnych rozwiązań. Szczegółowe wytyczne w tym zakresie znaleźć można między innymi w pracy [26].

Kolejną wadą rozpatrywanych systemów jest wrażliwość na jakość oraz ilość dopływających do nich wód deszczowych. Szczególnie obiekty podziemne charakteryzują się ograniczoną zdolnością usuwania zanieczyszczeń zawartych 
w wodzie opadowej. W przypadku braku dodatkowych urządzeń podczyszczających praktycznie uniemożliwia to ich zastosowanie, gdyż w odprowadzanych z terenów mieszkalnych wodach deszczowych zawarta jest znaczna ilość zawiesiny i skojarzonych z nią zanieczyszczeń, w tym metali ciężkich [5, 24]. Możliwość zastosowania poszczególnych rozwiązań systemów infiltracyjnych jest determinowana także ilością odprowadzanych do gruntu wód opadowych, która wynika z wielkości zlewni oraz intensywności i czasu trwania opadów. Najbardziej uniwersalne pod tym względem są skrzynki i komory drenażowe, gdyż mogą zostać wykorzystane zarówno jako pojedyncze urządzenia, jak i ich zespoły. Wdrożenie pozostałych rozwiązań systemów rozsączających wody deszczowe jest natomiast ograniczone przyjętymi powszechnie wymiarami stosowanych obiektów. Dodatkowo należy każdorazowo uwzględnić wielkość powierzchni udostępnionej do infiltracji, co może znacznie ograniczyć wachlarz dostępnych rozwiązań.

Za wadę systemów infiltracyjnych należy uznać także brak szerokiego doświadczenia $\mathrm{w}$ ich eksploatacji. W warunkach polskich dominującym sposobem zagospodarowania wód opadowych jest ich ujmowanie i odprowadzanie do odbiornika, natomiast rozwiązania proekologiczne, pomimo ich ciągłego rozpowszechniania, wciąż nie stanowią podstawowego narzędzia gospodarki wodami opadowymi.

Zastosowanie systemów infiltracyjnych wiąże się dodatkowo z koniecznością zagwarantowania bezpieczeństwa mieszkańców oraz innych użytkowników systemów odwodnieniowych. Powoduje to potrzebę regularnego czyszczenia i konserwacji eksploatowanych systemów, jak również przeciwdziałania obniżaniu się efektywności rozsączania wód deszczowych, przykładowo na skutek kolmatacji. W przypadku zbiorników infiltracyjnych, których napełnienie przekracza 0,3 m, konieczne jest także wykonanie ogrodzenia [26].

Wybór strategii implementacji systemów infiltracyjnych, oprócz zidentyfikowania ich mocnych i słabych stron, wymaga również przeanalizowania czynników zewnętrznych związanych z rozpatrywanym procesem, to jest potencjalnych szans i zagrożeń.

Dzięki zredukowaniu ilości ścieków deszczowych odprowadzanych do odbiornika zmniejsza się niebezpieczeństwo nadmiernego wzrostu poziomu wody w rzekach, jak również przeciążenia istniejących kolektorów kanalizacyjnych, co znacznie obniża ryzyko powodziowe. Szansą dla badanych systemów jest więc ograniczenie strat związanych $\mathrm{z}$ podtopieniami, zarówno tych materialnych, wynikłych z zalewania gospodarstw domowych, jak i społecznych, takich jak utrata zdrowia.

Za powszechnym stosowaniem analizowanych systemów przemawia także poprawa stanu rzek, która wynika ze wzrostu zasilania cieków powierzchniowych wodami gruntowymi oraz z ograniczenia dopływu nieoczyszczonych ścieków deszczowych. Zredukowanie ilości doprowadzanych do odbiornika ścieków, zarówno tych transportowanych przewodami kanalizacji deszczowej, jak 
i tych pochodzących z przelewów burzowych czy przelewów awaryjnych oczyszczalni ścieków, może się bowiem przyczynić do zmniejszenia zanieczyszczenia fizyko-chemicznego i biologicznego wód odbiornika. To z kolei wpłynie pozytywnie na stan flory i fauny w rzece. Dodatkowo spowolnieniu ulegnie także proces niszczenia koryt rzecznych związany z dopływem nadmiernych ilości ścieków.

Do pozytywnych czynników zewnętrznych należy także poprawa funkcjonowania sieci odwodnieniowych oraz wzrost efektywności działania obiektów kanalizacyjnych, takich jak przelewy, separatory czy oczyszczalnie ścieków. Wynika to z faktu, iż zagospodarowanie wód deszczowych w miejscu ich powstania pozwala ograniczyć wahania przepływów ścieków doprowadzanych do poszczególnych urządzeń, w efekcie czego zredukowaniu ulega także ryzyko niedostosowania rozwiązań konstrukcyjnych tych urządzeń oraz zastosowanej technologii oczyszczania ścieków do ich ilości.

Ponadto do szans systemów przeznaczonych do infiltracji wód deszczowych do gruntu zaliczyć należy wzrost świadomości ekologicznej oraz propagowanie zastosowania zrównoważonych technologii i urządzeń wśród mieszkańców. Wpajanie od najmłodszych lat troski o jakość środowiska naturalnego może się bowiem przyczynić do zwiększenia stopnia akceptacji takich rozwiązań, a dzięki temu także stopnia ich implementacji w zlewniach miejskich.

Następną szansą uwzględnioną w analizie jest polepszenie atrakcyjności terenów miejskich. Zagospodarowanie wód deszczowych w obrębie zlewni, w której powstają, umożliwi poprawę jej bilansu wodnego, co z kolei wpłynie pozytywnie na wzrost różnorodności biologicznej na terenie miast. Zastosowanie urządzeń charakteryzujących się wysokimi walorami krajobrazowymi pozwoli także wytworzyć przyjazną mieszkańcom strefę miejską oraz umożliwi wzrost wartości nieruchomości zlokalizowanych w jej sąsiedztwie.

Do głównych zagrożeń rozpatrywanych systemów należą natomiast zmiany klimatu. Projektanci ani eksploatatorzy systemów infiltracyjnych nie są w stanie przewidzieć natężenia ani rozkładu opadów w kolejnych latach. Prognozowany wzrost intensywności opadów ekstremalnych może więc doprowadzić do przeciążenia urządzeń projektowanych na podstawie stosowanych powszechnie wytycznych oraz obniżenia ich efektywności. Wydłużenie okresów bezdeszczowych może z kolei skutkować niewykorzystaniem ich projektowanej pojemności.

Kolejnym aspektem, który należy wziąć pod uwagę projektując systemy rozsączania wód deszczowych, jest możliwość wprowadzenia niekorzystnych wytycznych w tym zakresie. Regulacje prawne dotyczące możliwości zastosowania urządzeń infiltracyjnych są obecnie w Polsce ograniczone do minimum [27], co może być przyczyną uchwalenia konkretnych unormowań w niedalekiej przyszłości.

Zagrożeniem dla analizowanych systemów jest także ryzyko nadmiernego zanieczyszczenia wód deszczowych podczas kontaktu kropli deszczu z powie- 
trzem oraz w czasie spływu powierzchniowego. Nieprzewidziany wzrost ładunku zanieczyszczeń w odprowadzanej do gruntu wodzie opadowej może bowiem wpłynąć niekorzystnie na stan wód podziemnych.

Do negatywnych czynników zewnętrznych należy również brak akceptacji ze strony mieszkańców, który spowodowany jest przyzwyczajeniem do tradycyjnych rozwiązań oraz niewystarczającą wiedzą na temat zrównoważonego gospodarowania wodami opadowymi. Problemem może być także błędne przeświadczenie o ekologiczności stosowanych rozwiązań. Przykładowo niektóre nawierzchnie, które wyglądają na przepuszczalne, w rzeczywistości mogą być wykonane $\mathrm{z}$ barwionego bądź tłoczonego betonu.

\subsection{Wybór strategii rozwoju systemów przeznaczonych do infiltracji wód opadowych}

Kolejnym etapem przeprowadzonej analizy było ustalenie wag czynników przypisanych do poszczególnych grup oraz określenie relacji występujących między nimi. W badaniach uwzględniono zarówno powiązania wyznaczone metodą SWOT („,od wewnątrz do zewnętrz”), jak i TOWS („od zewnątrz do wewnątrz"), co wymagało utworzenia ośmiu tablic pomocniczych. Przykład tablicy sporządzonej w celu przeanalizowania relacji między mocnymi stronami systemów przeznaczonych do infiltracji wód opadowych do gruntu a potencjalnymi szansami wynikającymi z ich aplikacji na terenie osiedli mieszkaniowych przedstawia tabela 1. Zgodnie z wytycznymi opisanymi w pracy [20] występowanie interakcji między danymi czynnikami oznaczono jako „1”, natomiast jej brak - jako „,". Numeracja poszczególnych elementów zbiorów czynników pozytywnych odpowiada numeracji z rysunku 3.

Zbiorcze wyniki analizy SWOT/TOWS systemów przeznaczonych do infiltracji wód opadowych do gruntu zestawiono z kolei w tabeli 2. Wytłuszczoną czcionką oznaczono największą liczbę interakcji oraz najwyższe wartości sumy iloczynów uzyskane w poszczególnych badaniach.

Przeprowadzona analiza SWOT wykazała, że największa liczba interakcji występuje między słabymi stronami rozpatrywanych systemów i potencjalnymi szansami. Taka konfiguracja wyników wskazuje na potrzebę usuwania negatywnych czynników wewnętrznych, które mogą utrudnić wykorzystanie pojawiających się szans. Wyeliminowanie wszystkich wad systemów infiltracyjnych, przykładowo uzależnienia możliwości ich zastosowania od warunków gruntowo-wodnych zlewni, z pewnością nie będzie możliwe. Znaczenie pozostałych słabych stron rozpatrywanych systemów, takich jak brak doświadczenia w ich eksploatacji, może jednak zostać znacząco zredukowane. 
Tabela 1. SWOT: Identyfikacja powiązań między mocnymi stronami systemów infiltracyjnych a potencjalnymi szansami wynikającymi z ich aplikacji na terenie osiedli mieszkaniowych

Table 1. SWOT: Identification of relations between stormwater infiltration systems strengths and potential opportunities of their application in residential areas

\begin{tabular}{|c|c|c|c|c|c|c|c|c|c|}
\hline $\begin{array}{l}\text { Szanse } \\
\text { Mtrocne }\end{array}$ & 1 & 2 & 3 & 4 & 5 & Waga & $\begin{array}{c}\text { Liczba } \\
\text { interakcji }\end{array}$ & $\begin{array}{l}\text { Iloczyn wag } \\
\text { i interakcji }\end{array}$ & Ranga \\
\hline 1 & 1 & 1 & 1 & 0 & 1 & 0,3 & 4 & 1,2 & 1 \\
\hline 2 & 0 & 1 & 0 & 0 & 1 & 0,3 & 2 & 0,6 & 3 \\
\hline 3 & 0 & 0 & 1 & 0 & 1 & 0,1 & 2 & 0,2 & $4 / 5$ \\
\hline 4 & 0 & 0 & 0 & 1 & 1 & 0,1 & 2 & 0,2 & $4 / 5$ \\
\hline 5 & 1 & 1 & 1 & 1 & 1 & 0,2 & 5 & 1,0 & 2 \\
\hline Waga & 0,2 & 0,3 & 0,3 & 0,1 & 0,1 & & & & \\
\hline $\begin{array}{c}\text { Liczba } \\
\text { interakcji }\end{array}$ & 2 & 3 & 3 & 2 & 5 & & & & \\
\hline $\begin{array}{c}\text { Iloczyn wag } \\
\text { i interakcji }\end{array}$ & 0,4 & 0,9 & 0,9 & 0,2 & 0,5 & & & & \\
\hline Ranga & 4 & $1 / 2$ & $1 / 2$ & 5 & 3 & & & & \\
\hline $\begin{array}{c}\text { Suma } \\
\text { interakcji }\end{array}$ & & & & & & & $30 / 2$ & & \\
\hline $\begin{array}{c}\text { Suma } \\
\text { iloczynów }\end{array}$ & & & & & & & & 6,1 & \\
\hline
\end{tabular}

Wyniki analizy powiązań TOWS wskazują natomiast na przewagę interakcji między mocnymi stronami analizowanych systemów oraz potencjalnymi szansami, co pozwoli wzmocnić zalety systemów stosowanych w celu odprowadzania wód deszczowych do gruntu oraz umożliwi ich dynamiczną ekspansję. Tendencję tę potwierdzają także kompleksowe badania SWOT/TOWS. W przypadku pozytywnych czynników wewnętrznych i zewnętrznych łączna liczba interakcji wynosi aż 70, a suma iloczynów przekracza 14,0, co znacznie przewyższa wyniki uzyskane dla pozostałych kombinacji. Dla przykładu, wyniki analizy przeprowadzonej dla czynników zdefiniowanych w grupach słabych stron i zagrożeń są o prawie $40 \%$ niższe. 
Tabela 2. Zestawienie wyników analizy SWOT/TOWS

Table 2. The summary of SWOT/TOWS analysis results

\begin{tabular}{|c|c|c|c|c|c|c|}
\hline \multirow{2}{*}{ Kombinacja } & \multicolumn{2}{|c|}{$\begin{array}{c}\text { Wyniki analizy } \\
\text { SWOT }\end{array}$} & \multicolumn{2}{c|}{$\begin{array}{c}\text { Wyniki analizy } \\
\text { TOWS }\end{array}$} & \multicolumn{2}{c|}{$\begin{array}{c}\text { Wyniki analizy } \\
\text { SWOT/TOWS }\end{array}$} \\
\cline { 2 - 7 } & $\begin{array}{c}\text { Suma } \\
\text { interakcji }\end{array}$ & $\begin{array}{c}\text { Suma } \\
\text { iloczynów }\end{array}$ & $\begin{array}{c}\text { Suma } \\
\text { interakcji }\end{array}$ & $\begin{array}{c}\text { Suma } \\
\text { iloczynów }\end{array}$ & $\begin{array}{c}\text { Suma } \\
\text { interakcji }\end{array}$ & $\begin{array}{c}\text { Suma } \\
\text { iloczynów }\end{array}$ \\
\hline $\begin{array}{c}\text { Mocne } \\
\text { strony/ } \\
\text { Szanse }\end{array}$ & $30 / 2$ & 6,1 & $\mathbf{4 0 / 2}$ & $\mathbf{8 , 1}$ & $\mathbf{7 0 / 2}$ & $\mathbf{1 4 , 2}$ \\
\hline $\begin{array}{c}\text { Mocne } \\
\text { strony/ } \\
\text { Zagrożenia }\end{array}$ & $20 / 2$ & 4,3 & $36 / 2$ & 7,2 & $56 / 2$ & 11,5 \\
\hline $\begin{array}{c}\text { Stabe } \\
\text { strony/ } \\
\text { Szanse }\end{array}$ & $\mathbf{3 6 / 2}$ & $\mathbf{7 , 6}$ & $22 / 2$ & 4,2 & $58 / 2$ & 11,8 \\
\hline $\begin{array}{c}\text { Stabe } \\
\text { strony/ } \\
\text { Zagrożenia }\end{array}$ & $18 / 2$ & 3,6 & $26 / 2$ & 5,3 & $44 / 2$ & 8,9 \\
\hline
\end{tabular}

\section{Podsumowanie}

Zarówno wyniki analizy SWOT, jak i kompleksowych badań SWOT/TOWS, wskazują na znaczny potencjał systemów przeznaczonych do rozsączania wód opadowych do gruntu. Potencjał ten wynika głównie ze sprzyjających ich rozwojowi szans, takich jak: zredukowanie strat związanych $\mathrm{z}$ podtopieniami terenu, ograniczenie niekorzystnych zjawisk zachodzących w wodach powierzchniowych, wzrost efektywności systemów odwodnieniowych, poprawa świadomości ekologicznej mieszkańców czy polepszenie atrakcyjności osiedli mieszkaniowych. Należy więc dążyć do jak największego wykorzystania tych szans poprzez posiadane przez systemy infiltracyjne mocne strony, które związane są ze zmniejszeniem ilości odprowadzanych do odbiornika wód deszczowych, zasilaniem zasobów wód podziemnych, wysokimi walorami krajobrazowymi, stosunkowo niskimi kosztami cyklu życia poszczególnych urządzeń, jak również ich wielofunkcyjnością.

Wykorzystanie potencjalnych szans wynikających z wprowadzania wód opadowych do gruntu nie będzie jednak możliwe, jeśli urządzenia przeznaczone do powierzchniowej i podziemnej infiltracji wód deszczowych nie znajdą szerokiego zastosowania w zlewniach miejskich. $\mathrm{Z}$ tego względu bardzo ważną kwestią pozostaje edukacja społeczeństwa i propagowanie implementacji zrównoważonych technik gospodarowania wodami opadowymi, gdyż tylko w taki sposób uda się częściowo osłabić wady analizowanych systemów oraz przezwycię- 
żyć ewentualne zagrożenia. Należy także pamiętać, że niektóre cechy zlewni, w tym niesprzyjające warunki gruntowo-wodne, mogą znacząco ograniczyć możliwości aplikacji poszczególnych rozwiązań. Powoduje to potrzebę każdorazowego przeprowadzania szczegółowej analizy potencjalnych wariantów inwestycyjnych oraz wyboru tych, których zastosowania w terenie o określonej specyfikacji będzie uzasadnione technicznie i ekonomicznie oraz zostanie zaakceptowane przez społeczność lokalną.

Należy także zwrócić uwagę na fakt, iż przedstawione w artykule wyniki badań dotyczą wyłącznie wód opadowych odprowadzanych z dzielnic mieszkaniowych. Co prawda w przypadku terenów zielonych zastosowanie systemów infiltracji wód deszczowych $\mathrm{z}$ pewnością pozostanie najkorzystniejszą formą zagospodarowania tego medium, jednakże w sytuacji, gdy wody opadowe odprowadzane są ze zlewni charakteryzujących się znacznym zanieczyszczeniem, przykładowo z terenów przemysłowych, aplikacja urządzeń rozsączających wody opadowe może się okazać niemożliwa.

\section{Literatura}

[1] Al-Rubaei A.M., Viklander M., Blecken G.T.: Long-term hydraulic performance of stormwater infiltration systems, Urban Water Journal, vol. 12, 2015, pp. 660-671.

[2] Analiza SWOT, http://analiza-swot.pl/ \{dostęp: 12.02.2016 r.\}.

[3] Azarnivand A., Hashemi-Madani F.S., Banihabib M.E.: Extended fuzzy analytic hierarchy process approach in water and environmental management (case study: Lake Urmia Basin, Iran), Environmental Earth Sciences, vol. 73, 2015, pp. 13-26.

[4] Bajkiewicz-Grabowska E., Mikulski Z.: Hydrologia ogólna, Wydawnictwo Naukowe PWN, Warszawa, 2008.

[5] Di Modugno M., Gioia A., Gorgoglione A., Iacobellis V., la Forgia G., Piccinni A.F., Ranieri E.: Build-Up/Wash-Off Monitoring and Assessment for Sustainable Management of First Flush in an Urban Area, Sustainability, vol. 7, 2015, pp. 5050-5070.

[6] Czarniecki D., Słyś D.: Analiza techniczna i finansowa wariantów ogrzewanie wody z wykorzystaniem pomp ciepła współpracujących z systemami rozsączania wody deszczowej w produkcji roślinnej, Czasopismo Inżynierii Lądowej, Środowiska i Architektury, z. 61 (3/I), 2014, s. 33-51.

[7] Dziopak J., Starzec M.: Wpływ kierunku i prędkości fali deszczu na kubaturę użytkową wielokomorowych zbiorników retencyjnych, Czasopismo Inżynierii Lądowej, Środowiska i Architektury, z. 61 (3/I), 2014, s. 83-93.

[8] GhaffarianHoseini A., Tookey J., GhaffarianHoseini A., Yusoff S.M., Hassan N.B.: State of the art of rainwater harvesting systems towards promoting green built environments: a review, Desalination and Water Treatment, vol. 57, 2016, pp. 95-104.

[9] Hou L.Z., Yang H., Li M.: Removal of chemical oxygen demand and dissolved nutrients by a sunken lawn infiltration system during intermittent storm events, Water Science and Technology, vol. 69, 2014, pp. 398-406. 
[10] Igliński B., Piechota G., Iglińska A., Cichosz M., Buczkowski R.: The study on the SWOT analysis of renewable energy sector on the example of the Pomorskie Voivodeship (Poland), Clean Technologies and Environmental Policy, vol. 18, 2016, pp. 45-61.

[11] Jaber J.O., Elkarmi F., Alasis E., Kostas A.: Employment of renewable energy in Jordan: Current status, SWOT and problem analysis, Renewable \& Sustainable Energy Reviews, vol. 49, 2015, pp. 490-499.

[12] Kallioras A., Pliaas F., Diamantis I., Kallergis G.: SWOT analysis in groundwater resources management of coastal aquifers: a case study from Greece, Water International, vol. 35, 2010, pp. 425-441.

[13] Kaposztasova D., Vranayova Z., Markovic G., Purcz P.: Rainwater Harvesting, Risk Assessment and Utilization in Kosice-City, Slovakia, Procedia Engineering, vol. 89, 2014, pp. 1500-1506.

[14] Kaźmierczak B., Kotowski A.: The influence of precipitation intensity growth on the urban drainage systems designing, Theoretical and Applied Climatology, vol. 118, 2014, pp. 285-296.

[15] Kordana S., Słyś D.: Analiza SWOT wykorzystania wody deszczowej w instalacjach wewnętrznych budynków, V Międzynarodowa Konferencja Naukowo-Techniczna INFRAEKO 2016 „Nowoczesne miasta, Infrastruktura i środowisko”, Rzeszów-Kraków 2016, s. 185-195.

[16] Kordana S., Słyś D.: Analiza kosztów cyklu życia skrzynek rozsączających, Czasopismo Inżynierii Lądowej, Środowiska i Architektury, z. 61 (3/I), 2014, s. $127-139$.

[17] Kumar K., Kozak J., Hundal L., Cox A., Zhang H., Granato T.: In-situ infiltration performance of different permeable pavements in a employee used parking lot - A four-year study, Journal of Environmental Management, vol. 167, 2016, pp. 8-14.

[18] Markovič G., Zeleňáková M., Vranayová Z., Kaposztásova D.: Research of Infiltration Facility Efficiency and Quality of Rainwater Harvested from Surface Runoff in Real Conditions [w:] Storm Water Management. Examples from Czech Republic, Slovakia and Poland, (pod red.) Hlavínek P., Zeleňáková M., Springer International Publishing Switzerland, Cham 2015, pp. 83-112.

[19] Mohamed M., El Kezza O., Abdel-Aaal M., Schellart A., Tait S.: Effects of coolant flow rate, groundwater table fluctuations and infiltration of rainwater on the efficiency of heat recovery from near surface soil layers, Geothermics, vol. 53, 2015, pp. 171-182.

[20] Obłój K.: Strategia organizacji, PWE, Warszawa 2007.

[21] Pochwat K., Słyś D.: Innowacyjny wysokosprawny zbiornik retencyjny wód deszczowych, Magazyn Autostrady, nr 1-2, 2016, s. 38-40.

[22] Sarsby A.: A Useful Guide to SWOT Analysis, Pansophix Limited, 2012.

[23] Shafique M., Kim R.: Low Impact Development Practices: A Review of Current Research and Recommendations For Future Directions, Ecological Chemistry and Engineering S, vol. 22, 2015, pp. 543-563. 
[24] Sillanpää N., Koivusalo H.: Stormwater quality during residential construction activities: influential variables, Hydrological Processes, vol. 29, 2015, pp. 4238-4251.

[25] Sleegers F., Brabec E.: Linear infiltration systems along urban streets: evaluating aesthetic values, Journal of Landscape Architecture, vol. 9, 2014, pp. 48-59.

[26] Słyś D.: Zrównoważone systemy odwodnienia miast, Dolnośląskie Wydawnictwo Edukacyjne, Wrocław 2013.

[27] Słyś D., Kordana S., Dziopak J.: The Law Regulations on the Subject of Rainwater Management in Poland [w:] Storm Water Management. Examples from Czech Republic, Slovakia and Poland, (pod red.) Hlavínek P., Zeleňáková M., Springer International Publishing Switzerland, Cham 2015, pp. 197-210.

[28] Talaei A., Ahadi M.S., Maghsoudy S.: Climate friendly technology transfer in the energy sector: A case study of Iran, Energy Policy, vol. 64, 2014, pp. 349-363.

[29] Zeleňáková M., Hudáková G.: The necessity of hydrogeological survey in infiltration systems design, Czasopismo Inżynierii Lądowej, Środowiska i Architektury, z. 61 (3/I), 2014, pp. 401-409.

[30] Zeleňáková M., Markovič G., Kaposztásová D., Vranayová Z.: Rainwater Management in Compliance With Sustainable Design of Buildings, Procedia Engineering, vol. 89, 2014, pp. 1515-1521.

[31] Zeng M., Ouyang S.J., Zhang Y.J., Shi H.: CCS technology development in China: Status, problems and countermeasures-Based on SWOT analysis, Renewable \& Sustainable Energy Reviews, vol. 39, 2014, pp. 604-616.

\section{SWOT ANALYSIS OF STORMWATER INFILTRATION SYSTEMS APPLICATION IN RESIDENTIAL AREAS}

\section{S u m m a r y}

The rapid development of the construction and transport sectors is the cause of the growing share of impermeable surfaces in the total catchment area. The consequence of this process is the significant increase in the amount of stormwater runoff, often resulting in the hydraulic overload of sewer systems as well as the deterioration of rivers. In order to prevent these unfavorable phenomena, sustainable drainage systems, including stormwater infiltration structures, should be used. The possibility of infiltration systems application is, however, dependent on a number of factors such as the position of groundwater table, the soil filtration coefficient and the quality and quantity of stormwater. For this reason, SWOT/TOWS analysis has been used to recognize the strengths and weaknesses of stormwater infiltration systems as well as the opportunities and threats arising from their use in residential areas. Moreover, the development strategy of these systems has been identified. The obtained analysis results, which are presented in this paper, indicate that stormwater infiltration into the ground can be a preferred alternative to its discharging to the receiving water body. It is, therefore, essential to minimize the weaknesses of stormwater infiltration systems and also use their strengths to take advantage of the potential opportunities.

Keywords: SWOT/TOWS analysis, stormwater management, stormwater infiltration devices, sustainable development 
DOI: 10.7862/rb.2016.161

Przestano do redakcji: 01.05.2016 $r$.

Przyjęto do druku: 28.06.2016r. 